\title{
Anthrovision
}

Vaneasa Online Journal

Vol. 7.2 | 2019

Epistemic Disobedience

\section{The Voice of the Sierra Nevada}

Intercultural Communication and De-colonial Strategies in the Arhuaco Filmmaking and Collaborations

\section{Agata Lulkowska}

\section{Q OpenEdition \\ 1 Journals}

\section{Electronic version}

URL: http://journals.openedition.org/anthrovision/5872

DOI: 10.4000/anthrovision.5872

ISSN: $2198-6754$

\section{Publisher}

VANEASA - Visual Anthropology Network of European Association of Social Anthropologists

\section{Electronic reference}

Agata Lulkowska, "The Voice of the Sierra Nevada", Anthrovision [Online], Vol. 7.2 | 2019, Online since 10 November 2020, connection on 27 January 2021. URL: http://journals.openedition.org/ anthrovision/5872 ; DOI: https://doi.org/10.4000/anthrovision.5872

This text was automatically generated on 27 January 2021.

(c) Anthrovision 


\title{
The Voice of the Sierra Nevada
}

\author{
Intercultural Communication and De-colonial Strategies in the Arhuaco \\ Filmmaking and Collaborations
}

\author{
Agata Lulkowska
}

\section{Acknowledgement}

I would like to express my gratitude to Amado Villafaña and Pablo Mora for allowing me to conduct this research. Pablo Mora enabled my initial contact with the Arhuaco filmmakers, and Amado Villafaña accepted me as the temporary addition to his filming crew, which gave me the most direct access to my participants' work. I formed an integral part of their team for four months (September 2015 - December 2015). Additionally, I would like to express my sincere gratitude to Luciana Martins for her constant guidance with my research, as well as to Omar Sarmiento for his continuous support and intellectual stimulation. Without them, and the many other people who made my project possible, this research would not have reached its current stage.

\section{Filmmaking as the Necessity, or Gaining Agency}

1 When the ELN guerrillas threatened Amado Villafaña, an Arhuaco farmer who lived a tranquil family life in the Sierra Nevada de Santa Marta in northern Colombia, he was left in a very uncomfortable situation. Refusing to collaborate with the guerrilla would put him in grave danger, but he was not willing to obey the ELN's requests. In desperation, he sought the guidance of a Mamo, the Arhuaco spiritual leader. Following the community's peaceful approach, the advice was to spread the knowledge of what was happening in the Sierra in the hope to seek allies. A violent response was not an option, as the Arhuacos were famous for their peaceful resistance. Villafaña decided that the most effective and far-reaching way to communicate his worries was using an audiovisual medium, hoping that its universal quality can make intercultural communication possible.

2 Up till that moment, the Arhuacos' exposure to film was minimal if not non-existent most of the community members live high in the mountains, away from cinemas, TV, and electricity, following very traditional lifestyles. On few occasions, they became 
subjects for Western filmmakers who arrived in the Sierra to portray the community (the Arhuacos are one of the four indigenous nations inhabiting the region, together with the Kogui, the Wiwa and the Kankuamos ${ }^{1}$ ). The most notable examples of external representations, some of which left a scar on the community's trust towards the film medium, were 'El Valle de los Arhuacos' (The Valley of the Arhuacos) by Vidal Antonio Rozo (1964), Robert Gardener's 'Ika Hands' (1988), and 'From the Heart of the World The Elder Brothers' Warning', together with its sequel, 'Aluna', by Alan Ereira (1990 and 2012, respectively). The first title was a plain, shameless attack on the Arhuaco community, depreciating the traditional values as worthless, if not dangerous. The latter, more contemporary titles, are much more subtle. Gardner's approach was centred on aesthetic and existential explorations, while Ereira focused on establishing himself as the link between the Arhuacos and the Western world. On the surface, the last two titles seem to be perfectly innocent depictions of the Kogui community. However, the Arhuacos claimed to be severely misrepresented by the filmmaker. Ereira concentrated purely on the Kogui community, denying the Arhuacos their voice and, as a result, presenting the inhabitants of the Sierra as unable to speak for themselves, as Villafaña's told me.

3 Indigenous movements, including filmmaking, are often understood as ways to 'complete a process of decolonisation' suggests Freya Schiwy (2009b: 9). She describes how native people in Latin America use audiovisual technology to revive indigenous cultures:

They see film as a means of challenging Western representations of Indians and as counteracting the colonisation of the soul, that is, the self-denigrating effects that colonialism and its aftermath have had on the perceptions and self-perceptions of indigenous communities. (Schiwy 2013: 648).

4 Taking Hall's definition of culture as a practice concerned with exchanging meanings as a point of departure, Gillian Rose defines representation as 'made meanings', which 'structure the way people behave in everyday life' (Rose 2012: location 396 of 933). However, she suggests, these representations are never transparent, and never innocent: they always remain mere interpretations. This, I insist, should be remembered when discussing the assumption of 'truth' in documentary filmmaking. Similarly, I second Geertz who states that 'what we call our data are really our own constructions of other people's constructions of what they and their compatriots are up to' (Geertz 1973: 9). This concept forms the basis for my understanding of what a visual representation of the 'Other' is. In many external depictions of the 'Other', we notice that 'the cinema provided its own logic of the spectacle: whatever is captured became an attraction by virtue of being filmed' (Russell 1991: 51).

With this context in mind, it is no surprise that Villafaña saw the potential in developing self-representation practices in the region, which aimed to establish the Arhuaco legacy as a culture determined to protect their values, and highly proactive in defending their rights. In her article on memory and photography among the Arhuacos, Catalina Muñoz suggests,

Arhuacos are not merely passive subjects of the imperial gaze; they can stand both sides of these photographs, also observing, interpreting and reusing the tools of colonisation in their struggle for resistance, self-representation and selfgovernment. [...] An indigenous media-maker re-signifies anthropological photographs from the early twentieth century, but his contemporary use is not entirely detached from a colonial history of which he is a part of. (Muñoz 2017: 377) 
As we will see below, reusing existing visual material is a common practice for Arhuaco filmmakers. Not only do they use existing images to apply a new interpretation to them, but they also re-enact scenes from the past in their pursue of intellectual resistance. This re-appropriation of the archive images serves the purpose of 'strengthening cultural identity': '[Villafaña] wants to produce Arhuaco narratives of their collective stories, that in denouncing foreign abuse portray the community as strong and resilient', where the images tell the story of 'empowered indigenous resistance' (Muñoz 2017: 387). I echo Muñoz's conclusion that Villafaña really understood the potential of using new media 'for the defense and conservation of the land, languages, culture and identity of the indigenous peoples of the Sierra' (Muñoz 2017: 388).

\section{The Politics of Representation}

7 Schiwy (2009a: 3) suggests that the subaltern status of indigenous techniques of representation, as a reaction to the 'hegemonic structure of thinking' resulted from a colonialist geopolitics which implies that the North (West) produces theoretical knowledge while the Third and Fourth worlds only produce culture, or in best cases, 'local knowledge'. She argues that 'when indigenous organisations employ the audiovisual medium, they are commonly considered oral cultures using Western technology' (Schiwy 2009a: 3). This suggests constant appropriations, implying that 'having emerged in capitalist, colonial and patriarchal contexts, audiovisual media carry the burden of a colonial geopolitics of knowledge' (Schiwy 2009a: 3). However, the situation in some countries, including Colombia, inspires optimism based on two observations, according to Schiwy: 'First, that video allows decentralised communication and representation; second, that the medium enables liberation from the requirements of literacy and state education' (Schiwy 2009b: 3). These two qualities offer some hope about the application of these technologies into indigenous lifestyles, providing an opportunity for relatively unconstrained self-expression. Such practices can serve to maintain communication which can reach beyond cultural divisions. Although the majority of indigenous media productions are not experimental and they avoid the confrontation with hegemonic cinematic codes, Schiwy claims that 'indigenous video activists demand the decolonisation of the medium and of geopolitics of knowledge' (2009a: 4). It is worth mentioning that what is commonly referred to as the 'West', for Villafaña starts with the non-indigenous part of the Colombian society and extends further to the rest of the non-indigenous world.

8 Having no prior experience in filmmaking, Villafaña found an advisor and collaborator in the person of Pablo Mora, an established Colombian anthropologist, filmmaker and film academic. With Mora's help, Villafaña secured the initial training and equipment which led to the establishment of the Centre of Communications Zhigoneshi in 2002. He naively thought that the first film would take a few months to make, but he had to wait till 2007 to release the first Zhigoneshi title. Mora (2015) underlines that this process was not an easy one, as initially, the technologies were not well-regarded by traditional communities. They compared taking photos of the landscape in the Sierra to showing 'naked pictures of a mother' because for them Sierra is their mother' (Mora 2015: 78). Only after making a spiritual payment, the Mamos accepted the work. Another difficult task was to fit the lengthy monologues of the elders into an edit. Other challenges were 
accommodating the body, the way to look at the camera, or imagining the spectator (or the one who threatens this world). One of the stages in Villafaña's formation was provided by the Javieriana University in Bogotá, which allowed him to make the use of their equipment in the Sala Matrix, their multimedia centre, and become familiar with the technology. As Maryluz Vallejo, the Communication Department Professor from Javieriana University who led the event with Mora and other academics, describes it:

At the Matrix technology room - a possibility offered by the Program of Journalism of Pontificia Universidad Javeriana - the native Amerindians of Sierra Nevada de Santa Marta, Colombia, went through a 'conversion' and digital convergence experience to create and develop their own independent media. With Mother Nature's due permission, they started a process of incorporating new technologies vis-à-vis the production of journalistic and audiovisual material in their languages supported by their traditional wisdom. (Vallejo 2009: 1)

Over the past decade, Zhigoneshi has made nine films; they participated in numerous international film festivals, academic presentations, and local screenings at the indigenous villages in the Sierra. In 2012 they also published a beautifully designed DVD set simply called 'Zhigoneshi', which includes all their films². By participating at the international festivals and events, Villafaña and his team not only made a name for the Zhigoneshi productions but also initiated the communication with indigenous audiences which goes beyond the national and cultural borders. As Leuthold suggests,

Media technologies increasingly transmit the knowledge used in cross-cultural aesthetic appreciation. They cannot substitute for the direct experience, but they expose audiences to a wider range of aesthetic practices than direct experience [...]. Many people's sole knowledge of the aesthetic traditions of non-Western cultures derives from film and video [...]. Exotic, frequently stereotyped images in more widely distributed fiction films also shape public perception of other cultures. (Leuthold 1998: 11)

\section{Ethnographic Dialogue}

10 I arrived in the Sierra in September 2015 with the aim of documenting Arhuaco filmmaking in order to understand their self-representation practices, the objectives and ambitions, and finally the outcome with its consequences. It was not my first visit to Colombia, and I had previous experience of filming with another indigenous group in Peru, the Yanesha. For the duration of my stay, I become an integral member of the team. This involved accompanying them to the villages around the Sierra where they conducted extensive talks about communication, supporting the filming and the editing process, and documenting their work in order to understand the phenomenon of their success. Inevitably, a friendship was established with these immensely hospitable and helpful people. It quickly became apparent that all the expectations and assumptions about the filmmakers from the Sierra need to be reset and reestablished the image of closed and isolated peoples of the Sierra could not be further from the truth. As already established, the entire filmmaking practices exercised by the communities served nothing more than establishing communication with the nonindigenous world. Villafaña turned out to be very vocal about his involvement in the protection of the Sierra, and he liked to be in control of both of his work and of his image. The level of his self-awareness and the meticulous choice of words were exceptional. He was extremely clear about his goals and the way to achieve them, and he never missed the opportunity to approach the people who could influence the 
success of his work. With such attitude and his incredibly charismatic personality, he quickly managed to establish his authority and gain respect within his community and beyond. As such, he contributed to the process of strengthening the Arhuaco identity, even though it happened at the expense of his personal life (forced displacement and the inability to continue his preferred lifestyle in the mountains). Such an attitude has been echoed in Ginsburg's reflection on the intercultural qualities of indigenous media:

When other forms are no longer effective, indigenous media offer a possible means - social, cultural, and political - for reproducing and transforming cultural identity among people who have experienced massive political, geographic, and economic disruption. The capabilities of media to transcend boundaries of time, space and even language are being used effectively to mediate, literally, historically produced social ruptures and to help construct identities that link past and present in ways appropriate to contemporary conditions. (Ginsburg 1991: 94)

\section{The Power of the Image, Narrative and Storytelling}

In their endeavours, Villafaña and his team made a significant effort to understand the expectations of non-indigenous spectators and the way to capture their attention. The universal values of narrative and storytelling have played a huge role in that process. Villafaña had an apparent affection for all the technical aspects of image-making, and he often commented on the lenses, aperture, depth of field, composition or lighting. He was extremely clear and precise about what kind of images he wanted to capture and he displayed a very professional attitude towards filmmaking. On many occasions, he woke up at dawn to secure the perfect lighting at the shooting location.

There are several elements which can be identified as crucial for the Zhigoneshi's aims. Firstly, they were extremely protective of the ownership of the images made in the Sierra. This resulted from past misinterpretations, which not only did not seek approval from the communities but also did not share the intellectual property rights with its subjects. Villafaña's attempts to control the images created in the Sierra were close to obsession. He would personally assess every single film undertake in the Sierra, making sure that the intellectual ownership of these images remained in the hands of the community.

Secondly, he understood the value of the narrative, storytelling, and personal statements in filmmaking. In one of his films, 'Nabusímake', Villafaña uses his family history to teach three of his children (Angel, Gunza, and Dilia), and his audiences, about the tragic history of the Arhuacos in the past decades. He travels to a former orphanage established by the Capuchin missionaries in Nabusímake, the Arhuaco capital, where he recalls the torture and killing his family members were subjected to. However, his message is positive: it is crucial to remain active in remembering and disseminating the stories of this traumatic history - this will help to gain allies and prevent similar atrocities in the future. In 'Resistance on the Dark Line' Villafaña presents his people as passionate protectors of the indigenous values who make very skilful use of the archive materials and the situations unravelling in front of the camera. 'The Words of Wisdom' series, made in collaboration with Tele Caribe, a local Colombian TV, was designed to introduce some elements of the cultures of the Sierra to the TV audiences. With the last film, 'Naboba', Villafaña achieves a more subtle and toned-down effect. It looks as if the past films had a therapeutic effect on the filmmaker; he had dealt with the traumas of violence, displacement, misrepresentations, and contemporary threats, and was now 
ready to communicate the peaceful values of his culture and the wisdom of the elders. 'Naboba' focuses on the ecological concerns and the immense beauty of the Arhuaco lands, together with the harmonious determination of its people. All these films, and others not mentioned here, gave Villafaña the option to present his version of the Arhuaco history. More importantly, this exercise allowed him to present himself as a valuable participant in the intercultural film dialogue about the Sierra, and, by extension, about the politics of representation.

\section{Decolonial Strategy Versus 'Living Museums'}

But representation is rarely a straight-forward process. We should not forget that 'the representation of anything is by definition the creation of something different' (MacDougall 1998:48). Effectively, technology enables culture to be reproduced (Dicks 2004:9). But technology also distances us from the reality it aims to depict, and converts in into interpretations. This may create friction when many different points of view attempt to portray the same reality, resulting in competing versions which often do not agree with each other. There is also a visible tension between the (auto)representation ambitions and the claim of authenticity. And since consuming the culture on display can only be done in a fragmented way, "the commodification [...] can turn it into essentialized images of "otherness" seemingly frozen in time' (Dicks 2004:33). In some cases, such 'living museums' are deprived of the right to progress and could only survive by being utterly dependent on the flux of intrusive gaze of the visitors who "pay to watch'. In such situations, the performed display of cultural identity becomes a commodity to sell (Dicks 2004:63). MacDougall suggests that 'by fixing its subjects irrevocably in the past, a film encroaches on their freedom and identity' (MacDougall 1998:36). All these concerns and the understanding of the power of the image contributed to the strong need to auto-represent the Arhuaco culture. They gained agency of spokespeople of the misrepresented, and they made their voice heard. By including their films in the intercultural dialogue (multiple international screenings and film festivals across the globe), the community contributed to a more balanced vision of their world. That resonates with MacDougall's observation that 'my image of you, or many images of you in different situations, forms much of what I know about you' (MaxDougall 2006:5). A common expectation is that what we see in a documentary is as close to the real world as it could possibly be, but this promise cannot be fulfilled as representation processes, as already mentioned, are ruled by their own politics (Nichols 1991:11). Nichols suggests that documentaries are often based on 'longstanding assumptions,' frequently treated like commodities (for example, about the third world inferiority). This is what the Zhigoneshi attempt to contest in their collaborations.

\section{Collaborations}

15 Jay Ruby underlines that indigenous peoples acquire the technical knowledge essential to make their films in workshops and training provided by Western filmmakers, and the funding for these productions also usually comes from Western sources. Such a situation might appear paternalistic, although it remains the only way in which most indigenous peoples can gain the skills and obtain the technology which they require to satisfy their filmic ambitions (Ruby 2000: 216). Postulating collaborative filmmaking, 
Ruby sets out the rules: 'for a production to be truly collaborative, the parties involved must be equal in their competencies or have achieved an equitable division of labour' (Ruby 2000: 208).

Villafaña's view on collaboration is in line with this, and is based on the balance between allowing external input which can help disseminate the message of the community, but without giving everything away. His primary concern is to ensure that the image created by the external filmmakers is consistent with the community's view (or at least it does not contradict it) and does not distort the vision of its people. When he allows someone to film in the Sierra, a signed contract securing the intellectual ownership and the scope of permitted dissemination follows. Although he challenges the value of non-indigenous presence in any productions made in the Sierra, he also understands that there are certain aspects of his filmmaking practice which require a level of external help. Firstly, nobody in his team has truly mastered the art of montage, so most of the Zhigoneshi films were edited by Mora. Secondly, the team needs external help with the distribution of their productions. As suggested, Villafaña's established position as the spokesman for the Four Nations of the Sierra makes his external relations with festivals organisers, universities, and other art institutions potentially interested in his work much easier. Increasingly, it is he who accepts or rejects the invitations, as a growing number of proposals come his way. He is known to be very selective and cautious in his collaboration choices, remaining exceptionally protective of the intellectual property of the Sierra. Music, images, and the wisdom of the Mamos, together with the traditional Arhuaco clothing, are the collective property of the whole community and cannot belong to a single person (indigenous collective property as discussed by Riley, 2004 or von Lewinski 2008). The images of the Sierra also cannot be carelessly 'given away' to anybody who arrives there with the idea to make a film. This task requires a very skillful balance between jealous protection of what should remain in the Sierra and the amount of information (and images or music) which should be 'released' to the outside world. Villafaña is very clear that communication with the external world must be established as this is the requirement to create the strategies to protect all the elements of the indigenous life which matter to him and his community: the land, the language, nature, the music and traditional dance, etc. As such, the external filmmaking practices in the region can become a decisive factor which can help introduce the communities and their problems to the outside world and establish a dialogue with the non-indigenous partners. However, Villafaña warns against unfaithful interpretations which can cause more damage and potentially corrupt the relations and purposes of filming in the Sierra. He understood what MacDougall rightly stated: "The real "crime" of interpretation is representation itself. [...] By freezing life, every film to some degree offends against the complexity of people and the destiny that awaits them' (MacDougall 1998: 38).

17 Pablo Mora is the closest and the most loyal collaborator of Zhigoneshi, remaining the only non-indigenous member of the collective. His role is impossible to overestimate, and he remains the perfect link between the communities of the Sierra and the nonindigenous world of regulations, laws and paperwork. He provided the guidance, training, and secured funding which made the birth of Zhigoneshi collective possible. When I observed Mora and Villafaña working together, it was clear that not only the interest of the collaboration is close to both men's hearts, but during this journey with they established a genuine friendship. Although in his films Villafaña presents himself 
in a solemn manner often talking about a very tragic and traumatic past, it was a pleasant surprise to see that he is a youthful and optimistic family man whose favourite way of spending time was to enjoy the company of his children and grandchildren. Villafaña's tragic past, tortures, or displacement did not break his spirit, and it was often possible to see him smiling and throwing jokes at his team. Ultimately, he becomes an example of what Ruby advocates as the transformation of the 'disappearing Other' from a passive film subject and a 'victim' of Western influence, into an engaged collaborator and author (suggesting that for a long time they remained mere transformations into 'aesthetic creations, topics of scholarly interest, news items, and objects of pity and concern') (Ruby 2000: 199). What links to that, is a shift in authority. Leuthold implies that indigenous self-representations have more profound consequences both for the subjects but also for the assumptions of what art should be:

The very idea of 'self-representation' as a personal and political concept challenges traditional notions of the self, where the self is thought of in terms of 'subjectivity' or in the religious context of 'soul'. Western culture tends to separate the self into private and public dimensions, and this separation shows up in assumptions about art. (Leuthold 1998: 32)

18 As the level of technical proficiency improved with Zhigoneshi's subsequent films, so does the film language and the variety and sophistication of techniques applied to narrate the story. Two of the techniques commonly used in Zhigoneshi productions are the use of the archival materials and re-enactions based upon them. Most of the scenes re-enacted in the videos created by the collective are based on the photographs taken in the Sierra by Gustaf Bolinder, a Swedish ethnographer who conducted his fieldwork in the Sierra on two occasions. His first visit (1914-1915) was when he took a photograph of an indigenous girl tied to a pole, among others. For the Arhuacos, this image is a sad reminder of the oppressions imposed on their community by the Capuchins. On Bolinder's second visit (1920-1921), he photographed a scene with one of the missionaries and an indigenous man having his hair forcibly cut. In her analysis of his work, Muñoz observes that 'Bolinder took the pictures as ethnographic material that sought to capture the culture of what he perceived as an exotic tribe', a common approach at that time (Muñoz 2017: 376). Years later, all forty-two photographs he took during his visits were recovered from European archives by the anthropologist Yesid Campos and his study group, Associación del Trabajo Interdisciplinario, and delivered to the indigenous authorities in the Sierra. They are now kept in an album called 'Fotografías de Nabusímake en 1915 (Gustaf Bolinder)', created and by an elder, Manuel Chaparro, in Nabusímake, often remaining an inspiration for the reflection about the past (Muñoz 2017: 377). Muñoz points to the plurality of potential interpretations of the images that might be used in two different contexts: indigenous and non-indigenous ones (Muñoz 2017: 375). The initial one was as Bolinder's ethnographic document. Muñoz proposes that:

Today, some Arhuaco use them for different ends. They have recently incorporated them into narratives about their past, mobilised to strengthen their cultural identity and legitimise claims to autonomy. As such, the uses of these photographs can be interpreted as part of a wider Arhuaco effort to produce counter narratives of self-determination. (Muñoz 2017: 376)

19 This points to the role of photography in the construction of memory and 'the process through which the pictures become vehicles in the production of narratives about the past' (Muñoz 2017: 382). 


\section{The Voice of Sierra Nevada ${ }^{3}$}

20 Having gathered hours of footage during my fieldwork with the Zhigoneshi, I showed Villafaña the first edit. It was critical for me that he was aligned with the message I wanted to convey and that he did not feel misrepresented in any way. Villafaña was very helpful in offering his feedback, and he was hugely encouraging throughout the process. I divided the film into five chapters, each describing a different aspect of the self-representation practices and the communication strategies of the collective. The final edit was made in consultation with the extended team and Villafaña's family. They appreciated the honesty and the sense of humour presented in my interpretation, and they did not request any changes.

21 The first section of the film, after a short introduction, focuses on the production. The opening scene shows Villafaña directing a group of the Kogui man in the village of Dumingueka. He orders them to walk from the far end of the village, enter one of the gathering huts, and exit from the back of it. This scene was entirely improvised for purely visual purposes, with Villafaña vigorously leading the group, shouting his orders and making sure that his cameraman caught the right perspective. I edited this scene with Villafaña's statements reinforcing the importance of filmmaking as a selfpreservation strategy, where communities gain the agency to have their own voice, and are proactive in taking the self-representation duties seriously. Villafaña sees this process as the natural evolution of the external communication practices of his people: from the necessity to learn Spanish, to the requirement to read and write, and finishing with the audiovisual literacy. He analysed all the recorded material with his team, always looking for ways to improve. He never shied away from long working hours or uncomfortable conditions.

Further sections of the film focus on the discussion about who has the right to represent whom, for what reasons, and in which contexts. Mora and Villafaña discuss the films by Alan Ereira, criticising practices which should be avoided. The main accusation against the work of the British filmmaker in the region is that he focused exclusively on the Kogui community, ignoring the other three. Villafaña also recalls the failure to agree between the two different approaches to filming in the region: Ereira's professional attitude where all the content of the film is precisely pre-defined and ready to be executed according to the plan (a common practice for many professional filmmakers), and the indigenous one, much more organic and which requires proper collaboration between both sides with an equal division of rights and responsibilities. It might be argued that both parties' politicised view of each other's intentions led to fallout and a failure to continue the collaboration. Another reason for disagreement comes from Ereira's attempt to present himself as the only link between these two words. His message to his (Western) audiences seems to warn against any attempt to interfere with the communities' wish to be left in peace. In stark contrast to that, Zhigoneshi's main reason for filmmaking is to establish communication with the outside world. This inconsistency triggered a fierce criticism of Ereira's attitude as a marketing trick which serves nothing more but to boost his rating and audiences' interest. It is clear that although Ereira's aim was certainly not to damage the image of the communities of the Sierra, the lack of re-alignment with his subjects worked against his favour and made him lose the communities' trust. Moreover, his skilful craft as a director convinced Villafaña that he is more faithful to the form and technique 
rather than the goal of representing the communities of the Sierra faithfully. This alone was enough to make Ereira ill-matched with the Zhigoneshi's vision.

Another concern of the filmmakers of the Sierra is to communicate the worries which they might have, rather than beautiful images about the idyllic Sierra which have nothing in common with reality. This is where the two visions become incompatible as they assume two completely different functions: successful filmmaking with an engaging plot (as in the case of Ereira), and a strategy for adopting agency to decolonise of the image of the Arhuacos, Kogui, Wiwa and the Kankuamos. Finally, the difference between these two approaches lies in fundamentally different primacies: the one of the individual choices (and artistic decisions, in this case), and the one where the collective wellbeing stands before anything else. While Ereira's films convey nostalgia towards the disappearing world and the exclusivity of the director who has been 'chosen' to pass the Kogui message to the world, the films made by the Zhigoneshi often express sadness and even anger at the attempts to threaten the indigenous order and the way of living, as well as the lack of understanding of the importance of their role as the guardians of the planet. However, the incompatibility of these two different points of view is not necessarily unavoidable, and it results from the lack of identifying common goals and understanding between the two sides. This is precisely why Villafaña identifies communication as the primary goal in his filmmaking. He strongly criticises the approach of exclusivity displayed in some Wester films and the expectation of entering the 'magic world of the indigenous' which, as he claims, is far off from their daily preoccupations and worries.

Ereira's approach is an example of what Nichols identified as the realist documentary style where the camera's proof of the filmmaker 'being there' is what grounds the film in the historical world (Nichols 1991: 181). Saying that, it should be noted that Ereira is not an anthropologist and made his film for TV audiences. Nevertheless, Nichols' argument that the focus of some ethnographic films can shift from subjects to witnessing the ethnographer's presence seems very relevant here:

The ethnographic film offers an impression of authenticity by means of the arrival scene. This represents an ironic form of coming into the presence of the Other that certifies difference (the difference between the ethnographic visitor and his/her subject) and makes unity impossible. The ethnographer steps onto the scene, confiding to us his/her travails and hardships. The arrival scene offers an outward and manifest sign of the inner, subjective state of participatory observation. The irony is that the representation of the required subjectivity diminishes the material reality of encounter itself. Problems of interpretation, negotiations regarding space, supplies, physical assistance, the right to film or photograph, and the numerous everyday rituals of communication and exchange between human subjects slip from view. More important is the impression that the ethnographer was there and that his or her representation is, therefore, to be trusted. (Nichols 1991: 221)

This ethnographic presence in film is based on the very fundamental quality of photographic image, as defined by Barthes who reminded us that 'every photograph is a certificate of presence' (Barthes 2000: 87). Additionally, the ethnographic encounter might become a negotiation between the filmmaker and the subjects who might have different visions of the proposed representation. Rose suggests that some people 'may wish to picture themselves very differently from their representations in the mass media,' a trend clearly visible in the Arhuaco filmmaking (Rose 2012: 315). 
Another important question which is the consequence of the ethnographic encounter is the decision of what gets included in the film and what does not. As we could see on the example of Ereira's films, the omission was the main criticism which put his work in opposition to the Zhigoneshi's goals. Nichols insists that 'documentary reference to the world around us is not innocent. [...] What it includes and excludes, what it proposes and surprises remain issues of significance' (Nichols 1991: 140). An often-quoted observation by MacDougall illustrates the significance of omission in a film even further:

The viewfinder of the camera, one could say, has the opposite function of the gunsight that a soldier levels at his enemy. The latter frames an image for annihilation; the former frames an image for preservation, thereby annihilating the surrounding multitude of images which could have been formed at that precise moment of time and space. (MacDougall 1995: 123)

MacDougall also suggests that 'Films prove to be poor encyclopedias because of their emphasis upon specific and delimited events viewed from finite perspectives' (MacDougall 1995: 123). He adds that 'a few images create a world. We ignore the images that could have been but weren't. In most cases, we have no conception of what they might be' (MacDougall 1995: 123). As a result, we should be aware that documentary filmmaking offers a version of reality, out of many possible ones. Finally, could looking at others in order to represent them be so easily rationalised and justified by film-making or research? Could we ignore the questions of power, knowledge, hierarchy and scopophilic pleasure in that process? This resonates with Nichols who recalls the trouble with contemporary ethnography where 'representation becomes the province of Us discussing Them in ways that no longer matter very much to Them' (Nichols 1995: 86).

\section{Reversed Audiencing}

I have purposely contrasted fragments of the Zhigoneshi films with the ones made in the Sierra by the external filmmakers to demonstrate the difference in attitudes. In this comparison, it quickly becomes evident that while it looks attractive for a film to present the communities of the Sierra as the mysterious guardians of secret wisdom which we, the 'civilised' people, have lost, in reality, the daily life of the Arhuacos and the Kogui is a constant struggle against the invasive presence of the militaries, industry (mining and other), misappropriation of the gold of their ancestors, and the difficulties of the access to their sacred lands. These two visions are very different, and they were made with a different purpose in mind: the skilled Western representations by 'visiting' filmmakers are aimed at making an attractive portrait of the 'forgotten' culture, whilst the Zhigoneshi vision is to present the struggles and values of the culture which is very much alive and proactive in creating their audiovisual signature and a message to the non-indigenous world. I call this process a 'reversed audiencing', where the subject (or the 'Other') distorts the expected order of the spectatorship, and by watching the films about themselves (which were primarily aimed at Western audiences), they initiate the process of self-representation which decolonises their image and let them gain agency and active participation in the intercultural dialogue around the politics of representation. 
Mora goes as far as suggesting that some of the non-indigenous representations of the communities of the Sierra are seen by them as ignorant and even symbolically violent. However, we have to be careful not to glorify a single indigenous point of view, insisting that only the internal view can be correct. Of course, they will always have a more in-depth insight into their own culture than someone who arrives for a few shooting days and makes a film based on a pre-designed script. However, it has to be said that many of the films by the 'visiting' filmmakers are based on extensive research and prolonged time spent with the communities. Additionally, an external view can sometimes be enriching as it brings a broader perspective and a fresh-eye view. Furthermore, it is worth noticing that although one of the main criticisms Villafaña had for the contemporary European films made in the region was that they focused solely on one out of the four communities (the Kogui), completely ignoring the other two, in his own filmmaking, he increasingly gravitates towards the Arhuaco-only focus. As a result, the Yokosovi collective has been established which focuses exclusively on the Arhuaco filmmaking, while the Zhigoneshi collective (both led by Villafaña) remains primarily focused on all four nations.

The Arhuacos' concern about the potential misrepresentations of their culture is understandable when we think about the impact an image can have on potential audiences. Since all images and interpretations, and different films are made for different types of audiences, the complexity of the 'politics of interpretation' becomes apparent. Frantz Fanon notes that 'It is by their apparel that types of society first become known, whether through written accounts and photographic records or motion pictures' (Fanon 1967: 35). Similarly, Hall proposes that “"other cultures" are given meaning by the discourses and practices of exhibition in ethnographic museums of "the West" (Hall 1997: 225). These exhibitions have their own poetics (discourses) and politics (relations of power). In more contemporary contexts, ethnographic films and other forms of exhibition often acquire a similar role. The discourse surrounding these practices is significantly contributing to the fact of how these 'Other cultures' are being seen and given meaning. Therefore, the politics of representation cannot be seen as innocent (Hall 1997: 223-225). Hall speaks about the symbolic cultural power, the 'power to represent someone or something in a certain way.' He compares stereotyping to a 'symbolic violence' in this exercise of representational practices (Hall 1997: 259). But it is not only about stereotypes, but also about who creates the knowledge. Bhabha criticises the Eurocentric hegemony of knowledge, affirming that 'there is a damaging and self-defeating assumption that theory is necessarily the elite language of the socially and culturally privileged' (Bhabha 1994: 28). We can apply a similar accusation to the power relations between filmmakers/ethnographers and their subjects. Bhabha blames the 'structure of symbolic representation itself' for the cultural text's insufficiency to become a satisfactory 'act of cultural enunciation' (Bhabha 1994: 28). Furthermore, we face the problem of the 'ambivalence in [the] act of interpretation' (Bhabha 1994: 28). Film subjects often get reduced to a few stereotypes, easily recognisable by the Western audiences. To paraphrase Nichols, we witness a practice where the 'Other' in an ethnographic film is being used to support the Western filmmakers' arguments. Famously disliking ethnographic film, Nichols summarises it as a 'great anthropological generalisation' and 'small quaint descriptions' (Nichols 1991: 219). Avoiding these issues led Villafaña to focus on internal and external practices leading to decolonise the image of the communities of the Sierra. 
31 In the article analysing his work with the Kayapo community from Brazil, Terence Turner focuses on an essential attribute of indigenous film productions: 'The indigenous film maker's employment of his/her own cultural categories in the production of the video may reveal their essential character more clearly than the completed video text itself' (Turner 1992: 8). This suggests that 'the production of the medium itself "mediates" the indigenous categories and cultural forms that constitute its subject matter' (Turner 1992: 8). Like in the case of the Zhigoneshi collective, the Kayapos' main focus is placed on processes of production, reception, media as 'mediation', and the questions of identity and representation play the central role. Turner points that the difference between mediation in indigenous media versus ethnographic film and video is that the first one concerns the act of filmmaking itself: 'video takes on political and social importance in an indigenous community'. The filmmaking practice itself has visible effects upon the communities; more specifically on the social or cultural consciousness of the people filmed (Turner 1992: 6). 'The act of shooting with a video camera can become an even more important mediator of their relations with the dominant Western culture than the video document itself', suggests Turner (Turner 1992: 7). Turner's conclusion on the impact of the Kayapo filmmaking sounds very familiar to what happens in the Sierra Nevada: 'It seems fair to say that video has contributed to a transformation of Kayapo social consciousness, both in the sense of promoting a more objectified notion of social reality and of heightening their sense of their own agency by providing them with a means of active control over the process of objectification itself: the video camera' (Turner 1992: 11).

\section{Internal/External Work and Translations}

32 As already established, communicating with the external world lies at the centre of Zhigoneshi's concerns. However, it would be twrong to assume that technology and film language was their only challenge. There is also the question of internal communication which remains crucial to secure the consistency of the community's actions. Villafaña recognises the urgency of the internal aspect of his work, aimed at raising awareness among his people. He knows that protecting the land is not enough, and the attention also needs to be given to music, language, but also image, clothing and other elements of the Arhuaco identity. Both Mora and Villafaña admitted that the most challenging job was to get the Mamos' approval and support for the filmmaking. It does not come as a surprise that in a traditional culture where patience and lack of change are the chief virtues, and taking a photograph has bad connotations, the elders, whose job is to protect the traditional value and secure the continuity of the indigenous world, were far from enthusiastic about the newly adopted film medium. There were also not very eager to reveal the community secrets to an anonymous crowd. It took much effort to make them understand that in the contemporary contexts this is likely to be the most efficient way to achieve their aims, that is to protect the culture and secure its survival, rather than to betray the community's long preserved values. The turning point for Zhigoneshi was when the elders approved the work and conducted a spiritual 'cleansing' of the filming equipment.

But the image-making process has yet another dimension for the Zhigoneshi collective. Surprisingly, one of the members, a Kogui director Silvestre Gil, explains that the 'mother of images' lives in the Sierra and she is responsible for all the images, including the ones of the TV screens and photography. This, and other observations connecting 
indigenous and the non-indigenous worlds, were explored in 'Sey Arimaku', a fascinating film made by Mora where he explains the history of his collaborations with Villafaña and explores some unexpected links between the two worlds. Referring to Plato and Barthes, he finds surprising similarities between the Arhuacos with the nonindigenous world. This leaves us reassured that these two words are not entirely separate and perhaps they just need some process of translation to gain mutual understanding.

Any filmmaking, indigenous or not, is an attempt to 'translate' the direct life experience into the audiovisual medium. Many concepts and beliefs of the communities of the Sierra are based on the non-material world, hence 'showing' these in films might pose an even greater challenge. I was privileged to witness the process of translating the footage containing the monologues of the Mamos into Spanish and helping with the subtitles of the Zhigoneshi's films. I identified two main challenges in that process: the speeches of the Mamos are unusually long, as the elders are not used to express themselves in a lapidary way necessary for the film medium. This proves that the requirements of the film medium are not fully compatible with the community lifestyle and many adjustments had to be implemented. The 'translation' does not stop with turning life into a film. The second level of it starts with the challenge of translating the significance of the Arhuaco cosmology into something which can be deciphered by Western minds, not familiar with many indigenous concepts and ideas. As a result, the translation means not only moving from the Arhuaco language to Spanish but - more importantly - from the indigenous way of thinking into something which can be understood by anyone who is not familiar with the indigenous concepts. According to Villafaña, the wisdom of the Mamos is not accessible to anyone who is not from the community, as they will not reveal anything to people from beyond their own culture.

Here, we should also reflect on the relation between these two different points of view: the indigenous and the external one. Faye Ginsburg has advocated 'developing a framework that will allow us to think of the different but related projects of ethnographic film and indigenous media to each other' (Ginsburg 1995: 65). She claims, quite provocatively, that 'the presence of indigenous media production [...] has demonstrated the irrelevance of ethnographic filmmaking' (Ginsburg 1995: 68). I argue that these two are equally important, and they should enrich each other in the process of mutual understanding, contributing to a multicultural approach and respect for different points of view. In order to achieve that, efficient and respectful communication should be employed and maintained.

\section{Intercultural Communication}

Joy Hendry discusses questions of cultural exchange and personal identity. On many occasions, indigenous people actively engage in organising performances displaying their indigenous traits and values to the non-indigenous world. Hendry coins the term "cultural "reclamation"' to describe 'international links among and between indigenous peoples and outsiders interests in indigenous peoples' (Hendry 2005: 179). Hendry poses the question of how these tendencies of people reviving their cultural diversity spread globally, despite predictions of convergence, suggesting that this might be part of the global communications trend (Hendry 2005: 179). She also argues that what fuels mutual interest is precisely cultural difference, claiming that if indigenous people are willing to 'share their cultural treasures with the outside world, in their way and at 
their investigation, it can be to the benefit of both parties' (Hendry 2005: 196). She concludes with a revealing observation:

People whose ancestors have been made to suffer in the past have at least three choices in the way they react to the descendants of their aggressors. They can try to become part of the society of their aggressors, they can seek to take revenge, or they can try to heal the rifts. (Hendry 2005: 201)

Villafaña and Mora go above and beyond in their role as the ambassadors of what I call the 'Voice of the Sierra'. They took the initiative to organise a series of meetings with all the communities of the Sierra (except for the Kankuamos who are mostly assimilated in the mainstream Colombian society) to secure a common, agreed view on the communication practices between themselves and with the 'outside world'. During these meetings, they watched and analysed the existing films made in the Sierra (both internally and externally), and discussed the communications strategies which could strengthen their autonomy while enabling broadcast to the non-indigenous world. In appreciation of the courage to screen harmful past representations of the community, I agree with Muñoz who suggests that 'the production and dissemination of indigenous narratives about the past that denounce outside intervention in their culture and territory' can be seen as a form of a resistance (Muñoz 2017: 388). The choices to adopt different technologies are very conscious and strategic. For example, they fiercely rejected the presence of mobile network antennas on their territories (leaving them beyond any network reach), but they opted in for having a time slot in national and private TV channels where they could disseminate some carefully selected materials to the TV audiences. In discussion with the national TV authorities who came to Nabusímake to discuss the project, Villafaña and Mora openly discussed all the elements and steps necessary for the successful completion of the project.

In this process, they stumbled across some unexpected complications, such as the inability to register their work as a collective intellectual property (which would be the most appropriate for the indigenous filmmaking). As the result, they had to register their films as a property of the director, cameraman and producer. They proactively pushed for the implementation of new laws and regulations which could promote the ancestral knowledge as the source of communication. Based on my direct observations, the Arhuaco way of everyday communication is, in some aspects, very different from common Western standards. They exercise a direct democracy model with any significant decision-making: every single person needs to be present at the assemblies (including children), and every single person has the right to speak and express their concerns. Only when everybody agrees, the meeting can be concluded. I witnessed assemblies going on till early morning hours, with no breaks and no signs of impatience from the participants. But it is clear that Villafaña's ambition as communicator does not end in his village, and he has much wider audiences in mind.

However, communication only makes sense if the message is delivered and understood by its recipient. Whether it is accepted or contested is a matter of a secondary concern. One of the criticisms Villafaña received was that most of his films are made mainly in Spanish and seen by international festival audiences rather than the domestic ones. But I agree with Murillo when she notes that:

Solo aquel que domine la lengua nacional puede aspirar a convertirse en un líder cuya esfera de influencia vaya mucho mas allá de su propio pueblo, de su propio sector, de su propia localidad. Esta situación lingüística ha facilitado a algunos grupos el acceso a recursos del Estado y entidades internacionales que han 
posibilitado la formación de clases sociales claramente diferenciadas en la comunidad. ${ }^{4}$ (Murillo 2001: 145) continually keeping the bigger picture in mind, one can focus and reach the goal fully. He accepts that such an attitude means going more slowly and taking more time, but this is the only right way for him. He is aware of the importance of his work, knowing that this is just the beginning of the path which should be continued and developed in the years to come.

\section{Legacy and Perspectives for the Future}

44 At the time of my fieldwork, Villafaña was in his early sixties, and he already recognised the importance of passing the skills and the passion onto the younger generations. Throughout his filmmaking career, he closely collaborated with his children: Angel (who often took care of the microphones and sound recording), Dilia (who assisted with more general help), and Gunza (who was a protagonist of some of his films). In one of the interviews, he suggested that the richness of the communities of the Sierra should be shared with the outside world by implementing its elements into the non-indigenous educational system. Referring to Nichols' idea of cinema as a vehicle of domination, Raheja claims that documentary films attempt to educate their audience and compel them to perform a 'specific action' (Gilbert and Gleghorn 2014: 27). For Villafaña, this action is to secure allies and to protect the intellectual property 
of the Sierra. But Raheja questions the responsibility of self-representations and the effectiveness of accomplishing this task: 'is it possible for their films to change public opinion?' (Gilbert and Gleghorn 2014: 27). Another concern, suggests Ginsburg, is the application of Western systems (of intellectual property, among others) to commodify indigenous knowledge (Ginsburg 2006). At the same time, indigenous video-makers found a way to "take some steps to reverse processes through which aspects of their societies have been objectified, commodified, and appropriated' (Ginsburg 2006: 133). As demonstrated, creating an opposition to the commodified use of the images of indigenous communities created by non-indigenous filmmakers and ethnographers might be among the most significant reasons behind the emergence of indigenous media. However, this liberation does not come without a price, claims Ginsburg, as it 'threatens to be a final assault on culture, language, imagery, relationship between generations, and respect for traditional knowledge' (Ginsburg 1991: 96). This is due to the fact of adopting a new lifestyle (of a filmmaker-communicator), which in some cases might be fundamentally alien to the traditional values and habits of particular indigenous communities. And it is no different in the case of Villafaña. But the result is worth the effort: 'Indigenous videos document and enact cultural traditions of transmitting social memory as they seek to turn subalternised knowledge into sustainable knowledge' (Schiwy 2013: 658).

In my recent talks with Mora, he asked for my help with tracing European archives for any visual materials taken in the Arhuaco territories in the past. This only shows how far the community wants to push the idea of the control of the images and intellectual property. These efforts are noticed by Muñoz who argues that Villafaña 'contests Western historical narratives- by producing local one - while inventively partaking in Western storytelling technologies' (Muñoz 2017: 390).

\section{Conclusion}

The working title for my film changed several times, but I have settled on 'The Voice of Sierra Nevada.' What stood out to me during my stay in the Sierra was the amount of effort put into creating that voice and making sure that it is heard. Considering his unbeatable passion, it is astonishing to hear Villafaña's reassurances that he was previously never interested in image-making and that if not the violence in the region, he would have never reached for cameras. He often repeats that to fight for their case, it was indispensable to adopt some elements of non-indigenous lifestyle: first by learning to speak Spanish, then to write, and finally to use cameras. However, he finds it essential to learn how to communicate with the non-indigenous world to protect his culture. Difficulties and challenges never discouraged him, and he put all the effort and energy in securing that what he believes in gets heard. Villafaña's incredible charisma and people skills ensured him many allies and much interest around his work in festivals circles around the world. Understanding the importance of his task, he makes all the attempts to secure the training of the future generations who can follow his steps. Time will tell whether it was just a single golden decade in the Arhuaco filmmaking or the start of the ongoing tradition which can transform the way we look not only at the communities of the Sierra but also at film as a form of intercultural communication and decolonisation strategy. I conclude with Villafaña's words, where he explains the final goal of his activities: 
La meta es muy directa: La visibilización tiene que amarrar aliados para que estén con nosotros para la protección de la Sierra y la cultura. Yo creo que el producto va cumpliendo su propósito, lento, pero ahí va. Es importante que estemos posicionados en todos los festivales, a nivel nacional e internacional, porque es la manera de visibilizar lo que está pasando en la Sierra y cómo somos, y el propósito siempre es amarrar aliados. Sin embargo, la circulación la queremos hacer en espacios cerrados y no tan públicos. Ya cuando todo el mundo tiene acceso a ella, no todo el mundo es respetuoso, lo bajan, lo cortan, cogen imágenes, van a hacer videos a otro lado, entonces lo evitamos. De pronto bajo otras circunstancias incluso sería lo mejor, pero nosotros todavía no estamos preparados. Requiere de una explicación a las autoridades tradicionales en el territorio. Requiere de muchísima responsabilidad. ${ }^{6}$ (Villafaña 2013: 142)

\section{BIBLIOGRAPHY}

\section{Books and articles}

Barthes, Roland. 2000. Camera Lucida. London. Vintage Books.

Bhabha, Homi. 1994. The Location of Culture. London and New York. Routledge.

Dicks, Bella. 2004. Culture on Display: The Production of Contemporary Visitability. Issues in Cultural and Media Studies. London. Open University Press.

Fanon, Franz. 1967. A Dying Colonialism. New York. Grove Press.

Geertz, Clifford. 1973. The Interpretation of Cultures. New York. Basic Books.

Gilbert, Helen, and Gleghorn, Charlotte, eds. 2014. Recasting Commodity and Spectacle in the Indigenous Americas. London. Institute of Latin American Studies, School of Advanced Study, University of London.

Ginsburg, Faye. 1991. Indigenous Media: Faustian Contract or Global Village. Cultural Anthropology, Vol. 6, No. 1, pp. 92-112, Wiley.

Ginsburg, Faye. 1995. The Parallax Effect: The Impact of Aboriginal Media on Ethnographic Film. Visual Anthropology Review, Volume 11, Number 2.

Ginsburg, Faye. 2006. Rethinking Documentary in the Digital Age. Cinema Journal; Fall 2006, 46, 1. Research Library Core.

Gleghorn, Charlotte. 2013. Reconciliation En Minga: Indigenous Video and Social Justice in Colombia. Journal of Latin American Cultural Studies. Vol 22.2: 169-194, Taylor \& Francis.

Hall, Stuart, ed. 1997. Representation: Cultural Representations and Signifying Practices. London. SAGE Publications.

Hendry, Joy. 2005. Reclaiming Culture: Indigenous People and Self-Representation. New York. Palgrave Macmillan.

Hockins, Paul, ed. 1995. Principles of Visual Anthropology. Second Editions. Berlin, New York. Mouton de Gruyter. 
Leuthold, Steven. 1998. Indigenous Aesthetics, Native Art, Media and Identity. Austin. University of Texas Press.

Lulkowska, Agata. 2019. Voice of the Arhuacos: Transcending the Borders of "Indigenous" Filmmaking in Colombia. The Journal of Communication and Media Studies, Volume 4, Issue 2.

MacDougall, David. 2006. The Corporeal Image: Film, Ethnography and the Senses. Princeton and Oxford. Princeton University Press.

MacDougall, David. 1998. Transcultural Cinema. Princeton, New Jersey. Princeton University Press. Mora, Pablo. 2015. Poéticas de la Resistencia. El Video Indígena en Colombia. Bogotá. Cinemateca Distrital.

Muñoz, Catalina. 2017. Moving Pictures: Memory and Photography Among the Arhuaco of the Sierra Nevada de Santa Marta, Colombia. History and Anthropology, Vol. 28., No. 3, 375-37, Routledge.

Murillo, Luz A. 2001. Explorando el papel de la escuela en el mantenimiento de la lengua y la cultura Arhuaco. The University of Arizona.

Nichols, Bill. 1991. Representing Reality: Issues and Concepts in Documentary. Blooming and Indianapolis. Indiana University Press.

Nichols, Bill. 1995. Blurred Boundaries: Questions of Meaning in Contemporary Culture. Blooming and Indianapolis. Indiana University Press.

Riley, Mary, ed. 2004. Indigenous Intellectual Property Rights. Legal Obstacles and Innovative solutions. Walnut Creek, Lanham, New York, Toronto, Oxford. Altamira Press.

Rose, Gillian. 2012. Visual Methodologies: An Introduction to Researching with Visual Materials. Los Angeles, London, New Delhi, Singapore, Washington DC. Sage.

Ruby, Jay. 2000. Picturing Culture. Explorations of Film and Anthropology. The Chicago and London. University of Chicago Press.

Russel, Catherine. 1999. Experimental Ethnography: The Work of Film in the Age of Video. Duke University Press.

Schiwy, Freya. 2009a. Decolonizing The Technologies of Knowledge: Video and Indigenous Epistemology. Worlds and Knowledges Otherwise "Digital Decolonizations/Decolonizing the Digital" Dossier, https://globalstudies.trinity.duke.edu/projects/wko-digital-3 (accessed August 30, 2020).

Schiwy, Freya. 2009b. Indianizing Film: Decolonization, The Andes, and the Question of Technology. New Directions in International Studies. New Brunswick, New Jersey, London. Rutgers University Press.

Schiwy, Freya. 2013. Film, Indigenous Video, and the Lettered City's Visual Economy. A Companion to Latin American Literature and Culture. Ed. Sara Castro-Claren. Wiley-Blackwell.

Turner, Terrence. 1992. Defiant Images: The Kayapo Appropriation of Video. Anthropology Today Vol. 8, No. 6. Royal Anthropological Institute of Great Britain and Ireland.

Vallejo, Maryluz. 2009. La tecnología al servicio de la madre naturaleza/Technology for the Benefit of Mother Nature. Signo y Pensamiento, vol.28 no.54 Bogotá Jan./June 2009.

von Lewinski, Silke. 2008. Indigenous Heritage and Intellectual Property: Genetic Resources, Traditional Knowledge and Folklore. Second edition. Austin, Boston, Chicago, New York, The Netherlands. Kluwer Law International. 
Villafaña, Amado. 2013. La auto-representación se ha vuelto una necesidad en el video indígena: proteccionismos a la propiedad collective. Revista Chilena de antropología visual (21): 137-144.

\section{Films}

Ereira, Alan, dir. 2012. Aluna.

Ereira, Alan, dir. 1990. From the Heart of the World: Elder Brothers' Warning.

Gardner, Robert, dir. 1988. Ika Hands.

Lulkowska, Agata, dir. 2018 (director's cut); 2020. The Voice of Sierra Nevada.

Rozo, Vidal Antonio, dir. 1964. El Valle de los Arhuacos (Valley of the Arhuacos).

Zhigoneshi Collective. 2007. Yuawika sia: En el río del entendimiento (Yuawika sia: On the River of Understanding).

Zhigoneshi Collective. 2007. Yetsikin: Guardianes del agua (Yetsikin: The Water Guardians).

Zhigoneshi Collective. 2009. Palabras Mayores I (Words of Wisdom I).

Zhigoneshi Collective. 2009. Palabras Mayores II (Words of Wisdom II).

Zhigoneshi Collective. 2010. Yosokowi (Yosokowi).

Zhigoneshi Collective. 2010. Nabusímake: Memorias de una independiencia (Nabusímake: Memories of Independence).

Zhigoneshi Collective. 2011. Resistencia en la Línea Negra (Resistance on the Dark Line).

Zhigoneshi Collective. (Mora, Pablo, dir). 2012. Sey Arimaku: La otra oscuridad (Sey Arimaku: The Other Darkness).

Zhigoneshi Collective. (Villafaña, Amado, dir.) 2014. Naboba, visión ancestral del agua del pueblo Arhuaco (Naboba, Ancestral vision of the water of the Arhuaco peoples),

\section{NOTES}

1. All four indigenous communities inhabiting the Sierra are the direct descendants of the ancient Tayrona peoples. Nowadays, the Kankuamos lost their cultural attachment and adopted the Western lifestyle. The other three nations proudly continue with their traditions and reject any attempts of acculturation.

2. The full list of films included in the DVD set includes: 'Yuawika sia: En el río del entendimiento', 2007, (Yuawika sia: On the River of Understanding); 'Yetsikin: Guardianes del agua, 2007, (Yetsikin: The Water Guardians); Palabras Mayores I, 2009, (Words of Wisdom I); Palabras Mayores II, 2009, (Words of Wisdom II); Yosokowi, 2010, (Yosokowi); Nabusímake: Memorias de una independiencia, 2010, (Nabusímake: Memories of Independence); Resistencia en la Línea Negra, 2011, (Resistance on the Dark Line); and finally Sey Arimaku: La otra oscuridad, 2012, (Sey Arimaku: The Other Darkness).

3. The films' teaser can be found at: https://vimeo.com/253160759. It will be released in late 2020/early 2021 at selected film festivals. This article focuses mostly on the longer director's cut (64 mins), rather than the shorter 30 min version which will be released. The shorter version does not include, among others, the tension between the Arhuacos and Alan Ereira.

4. Only those who master the national language can aspire to become a leader whose sphere of influence goes far beyond your own people, your own sector, your own location. This linguistic 
situation has made it easier for some groups to access resources from the state and international entities, which enabled the formation of social classes clearly differentiated in the community. [Author's translation].

5. In another aspect of my research (which goes beyond the scope of this article), I conducted an extensive investigation at various film festivals of different type (ethnographic, artistic, indigenous, etc.). I also thoroughly analysed numerous case studies focused on representation the Other in film I order to locate the Zhigoneshi filmmaking in the context of broad politics of representation and international reception practices. I concluded, that the context of presentation (i.e. a profile of the festival) can sometimes overwhelmingly affect the reception process, often overshadowing the original tone of the film.

6. The goal is very clear: the visibility must bring together allies to be with us for the protection of the Sierra and its culture. I believe that the project is fulfilling its purpose, slowly, but there it goes. It is important that we are present in all festivals, nationally and internationally, because this is the way to make visible what is happening in the Sierra and how we are, and the purpose is always to gain more allies. However, we want to disseminate and circulate our wok in more closed spaces, not as much in public ones. When everyone has access to it, not everyone is respectful, they cut it, take images, go to make videos elsewhere, so we need to avoid it. Suddenly, under other circumstances, it would even be the best, but we are not ready yet. It requires an explanation to the traditional authorities in the territory. It requires a lot of responsibility [author's translation]. (http://www.rchav.cl/2013_21_b09_villafana.html\#6).

\section{ABSTRACTS}

Pondering on the power of cultural preconceptions, this article examines the tension between self-representation and 'representation from the outside'. Using the indigenous filmmaking practices of the Arhuaco community from Colombia as a case study, this article proposes that, thanks to the universal qualities of storytelling and narrative, film as a medium has the potential to bridge the intercultural gap and initiate an efficient knowledge exchange process. As such, it encapsulates the most effective way of establishing intercultural dialogue, regardless of the diverse backgrounds and aims of the creators and the audiences. The Arhuaco's prolific autorepresentation strategies which emerged as a response to violence and displacement served as efficient decolonisation strategy. The article demonstrates film's potential to become a successful tool to gain agency by communities traditionally denied the option to participate in intercultural communication.

En s'interrogeant sur le pouvoir des idées culturelles préconçues, cet article examine la tension entre l'auto-représentation et la "représentation de l'extérieur". En utilisant les pratiques cinématographiques indigènes de la communauté Arhuaco de Colombie comme étude de cas, cet article propose, grâce aux qualités universelles du récit et de la narration, que le film en tant que média a le potentiel de combler le fossé interculturel et d'initier un processus efficace d'échange de connaissances. En tant que tel, il résume la manière la plus efficace d'établir un dialogue interculturel, quels que soient les origines et les objectifs des créateurs et du public. Les stratégies d'auto-représentation prolifiques de l'Arhuaco, qui sont apparues comme une réponse à la violence et au déplacement, ont servi de stratégie de décolonisation efficace. L'article démontre le potentiel du film à devenir un outil efficace pour gagner l'adhésion des 
communautés qui se voient traditionnellement refuser la possibilité de participer à la communication interculturelle.

Reflexionando sobre el poder de las ideas culturales preconcebidas, este artículo examina la tensión entre la autorrepresentación y la "representación desde afuera". Utilizando como estudio de caso las prácticas cinematográficas indígenas de la comunidad Arhuaco de Colombia, este artículo propone que, gracias a las cualidades universales del relato y la narración (storytelling), el cine como medio tiene el potencial de unir la brecha intercultural e iniciar un proceso eficiente de intercambio de conocimientos. De esta forma, el cine posee la forma más eficaz para establecer un diálogo intercultural, independientemente de los diferentes bagajes y objetivos de los creadores y de las audiencias. Las prolíficas estrategias de autorrepresentación de los Arhuaco, que surgieron como una respuesta a la violencia y el desplazamiento, sirvieron como una estrategia de descolonización efectiva. El artículo demuestra el potencial del cine como herramienta potente para ganar agencia por parte de comunidades a las que tradicionalmente se les ha negado la opción de participar en la comunicación intercultural.

\section{INDEX}

Palabras claves: cine indígena, autorrepresentación, agencia, Colombia, Arhuacos, comunicación, intercultural, narración, narrativa

Keywords: indigenous filmmaking, auto-representation, agency, Colombia, Arhuacos, communication, intercultural, storytelling, narrative

Mots-clés: cinéma indigène, auto-représentation, organisation, Colombie, Arhuacos, communication, interculturel, récit, narration

\section{AUTHOR}

\section{AGATA LULKOWSKA}

Birkbeck, University of London, School of Arts (Currently: Lecturer in Film Production, Staffordshire University)

Agata Lulkowska is a Lecturer in Film Production at the Staffordshire University, interdisciplinary researcher, filmmaker and photographer. Former Artistic Director of the Discovering Latin America Film Festival in London. Currently, she is a Guest Editor for the Contribution to Humanities Journal and the Head of the Organising Committee for the Community and Communication Interdisciplinary International Conference. Recipient of the International Award for Excellence for The Journal of Communication and Media Studies, Premio Bertelli, and other international grants and awards. She is particularly interested in film as practice-based research, especially in intercultural and postcolonial contexts.

Agata.Lulkowska@staffs.ac.uk, agata.1@me.com 